КОЗАКОЗНАВЧІ СТУДІї

ISSN 2519-2523 (print)

Chornomors'ka mynuvshyna. - 2018. - No.13.

DOI: https://doi.org/10.18524/2519-2523.2018.13.149386

УДК 930(477)«18/19»

\title{
"THE COSSACK PERIOD" AS A HISTORIOGRAPHICAL CONCEPT IN THE WRITINGS ON THE LOCAL HISTORY OF DNIEPER REGION UKRAINE, XIX - BEGINNING OF XX CENTURY
}

\section{Lyudmyla Novikova}

PhD (History), Associate Professor

Odessa I. I. Mechnikov National University

2, Dvoryanska Str., Odessa, 65082, Ukraine

lyudmilanovikova@hotmail.com

In the article it is posed the problem of the existence of historiography concept of "the Cossack period" in the historiography of the local history of Dnieper region Ukraine in the epoch of the formation of modern Ukrainian nation. At that time the historiography of history of Ukraine was gradually transformed into an independent direction of research. In particularly this process was connected with the appearance of its own national history periodization. In this regard, the traditional Cossack theme which was concidered as Ukrainian in the conditions of the Russian Empire, to a certain extent had lost the role of the sole representative of history of Ukraine.

The Ukrainian historiography has expanded the horizons of Ukrainian history towards ancient times, for example, the times of Rus' (according the conception of Rus'Ukraine by V. B. Antonouych and M. S. Hrushevs'kyi) and earlier and also concedered the original development of contemporary Ukrainian society as a period of national revival. Accordingly the epoch of emerging and development of the Cossacks as a individual Ukrainian historical phenomenon was changed into the next stage of the history of Ukraine in modern model (paradigma) of its historical development. Therefor in the article it is paid attention to the emergence of the concept of "the Cossack period" in the context of general history of Ukraine.

At the same time, the historical researches in Dnieper region Ukraine which were of non-whole national Ukrainian, but of territorial, local character also contained in themselves the reflection of attempts to distinguish the concept of "the Cossack period" because they considered all periods available by sources in the history of the regions from antiquity (as to the South) to the present, or in the history of certain settlements they examined a consistent change of periods, starting from their foundation.

The article also paid attention to the different approaches of the authors to using the concept of "the Cossack period" in the historiography of the local history, proposed the three types of concept: people (narodnycky) type (or demographic, ethnographic, estate); political one (or political and state) (concerning the Hetmanate or Zaporoz'ka Sich); mixed people (narodnycky) and political one (Slobids'ka Ukraine).

As a result of the made research it was found that in the historiography of the history of different regions of Dnieper region Ukraine there were particular types of concept of "the Cossack period", depending on the local historical experience, the approaches of the individual authors and others. The influence of the concept of "the Cossack period", which was characteristic to V. B. Antonovich-M. S. Hrushevsky's national paradigm of history of Ukraine, according to used sources, is the most noted in the history of the Kharkiv, by D. I. Bagalij, who was V. B. Antonovich's disciple, although we can not exclude its effect towards the authors of the history of the city of Chernihiv. 
Key words: the concept of "the Cossack period", the modern historiography of Ukraine, the historiography of the history of different regions of Dnieper region Ukraine, the historiography of the history of settlements in Dnieper region Ukraine.

июдмила Новікова

Кандидат історичних наук, доцент Одеський національний університет імені I.І.Мечникова Вум. Дворянська, 2, Одеса, 65082, Україна lyudmilanovikova@hotmail.com

\section{"КОЗАЦЬКИЙ ПЕРІОД" ЯК ІСТОРІОГРАФІЧНИЙ КОНЦЕПТ У ПРАЦЯХ З МІСЦЕВОЇ ІСТОРІЇ НАДДНІПРЯНСЫКОЇ УКРАЇНИ, ХІХ - ПОЧАТОК XX СТ.}

У статті здійснена постановка проблеми існування історіографрічного кониепту "козаиький період" в історіографії місиевої історії Наддніпрянської України доби формування модерної української наиії. У ией час історіографія історії Украӥни поступово перетворюеться на самостійний напрямок досліджень, шо відбувалося, зокрема, за допомогою формування власної періодизаиї наиіональної історії. у зв'язку з иим традииійна козаиька тематика, ио визнавалася українською в умовах Російсъкої імперії, до певної міри втрачала роль єдиного репрезентанта історії України. Українсъка історіографія розширювала обрії історії України у давнину, наприклад, за рахунок Русі (у контексті кониепиії Русі-України В. Б. Антоновича та М. С. Грушевського) $і$ більи ранніх часів, а також осмислювала самобутній сучасний розвиток українського суспільства як період національного відродження. Відповідно доба появи та розвитку козацтва як окремого українсъкого історичного френомену перетворювалася на черговий етап в історії України у модерній моделі (парадигмі) ї̈ історичного розвитку, ио розроблялася В. Б. Антоновичем та М. С. Грушевсъким. Тому у статті приділена увага становленню кониепту "козаиького періоду" у контексті загальної історії України. Водночас історичні дослідження в Наддніпрянсъкій Україні не загальнонаиіонального українсъкого, а територіального, місиевого характеру теж містили в собі відображення спроб виділити кониепт "козаиького періоду", тому шло розглядали всі, доступні за джерелами, періоди в історії регіонів - від античності (в умовах півдня) до съогодення, або, в історії окремих населених пунктів, - послідовну зміну періодів, починаючи від їх заснування.

У статті також приділено увагу різним підходам авторів до використання кониепту "козаиького періоду" в історіографії місиевої історії, запропоновано виділення трьох типів кониепту: народнииького (демографрічного, етнографрічного, станового); політичного (державно-політичного) (у зв'язку з Гетьманшиною чи Запорозькою Січчю); змішаного народнииько-політичного (Слобідська Україна).

Внаслідок проведеного дослідження було з'ясовано, шо в історіографрії історії різних регіонів Наддніпрянсъкої Украӥни існували особливі типи кониепту "козаиького періоду", в залежності від місиевого історичного досвіду, підходів окремих авторів та ін. Вплив кониепту "козаиького періоду", властивого наиіональній парадигмі історії України В. Б. Антоновича-М. С. Грушевського, згідно використаним джерелам, найбільше виражений в історії міста Харкова, за авторством Д. І. Багалія, шо був учнем В. Б. Антоновича, хоча не можна виключати його вплив і на авторів історії м. Чернігова.

Ключові слова: кониепт "козаиъкого періоду", модерна історіографія України, історіографія історії окремих регіонів України, історіографія історії населених пунктів Наддніпрянсъкої України. 
Модерна історіографія історії України в Російській імперії переживала процес становлення як спеціальна дисципліна, предмет якої перетво-рювався на самостійний. Цей процес був багатовимірним, i знайшов своє відображення, зокрема, в історіографії історії окремих регіонів та населених пунктів Наддніпрянської України. При цьому необхідно відзначити, що увага до української складової їх історії приділялася авторами, що проводили дослідження на грунті різних історіографічних парадигм (моделей, взірців): як української національної, що остаточно була оформлена наприкінці XIX - на початку XX ст., української постдержавної (у якій, поряд з визнанням самобутності української історії, констатувалося припинення існування Гетьманщини та Запорозької Січі), так і територіальної (регіональної), імперської.

у свою чергу, поняття української історії часто асоціювалося 3 історією козацтва, і це було властиво і українській, i російській історіографії. Як відзначав М. С. Грушевський, у Російській імперії в історичній науці історія українського козацтва сприймалася як головний репрезентант історії української. Вчений вказував на вплив так званої традиційної схеми "руської історії", коли "...при українській історії, як вона звичайно мислила ся, зіставали ся тільки часи "Отпадения от Польши" й "присоединения к России", себто історія української козаччини, яка уривала ся 3 кінцем Гетьманщини безповоротно або продовжувалася ad libitum історією українського відродження" [1, с. 4]. Однак у ХІХ ст. поступово відбувався перегляд підходів до висвітлення загальної історії України, іiі межі розширювалися, зокрема, за рахунок Русі (згідно концепції РусіУкраїни) тощо. Тому втрачалася актуальність ототожнення історії України з історією козацтва, яка, в свою чергу, дає властиві характеристики вже окремому "козацькому періоду". Водночас необхідно відзначити, що історичні дослідження в Наддніпрянській Україні не загальнонаціонального українського, а територіального, місцевого характеру, теж містили в собі відображення спроб виділити концепт "козацького періоду", тому що розглядали всі, доступні за джерелами, періоди в історії регіонів - від античності (в умовах півдня) до сьогодення, або, в історії окремих населених пунктів, - послідовну зміну періодів, починаючи від їх заснування.

Мета даної статті полягає у тому, щоб виділити наукову проблему існування історіографічного концепту "козацький період" в історіографії місцевої історії Наддніпрянської України доби формування модерної української нації, з'ясувати особливості використання історіографічного концепту "козацького періоду" в різних регіонах, визначити його різні типи.

Актуальність дослідження пов'язана з недостатнім висвітленням в історіографії обраної дмя вивчення проблеми.

Об'єктом дослідження $є$ історіографія місцевої історії в Наддніпрянській Україні у XIX - на початку XX ст. Предметом дослідження виступають особцивості використання в історіографії місцевої історії Наддніпрянської України XIX - початку XX ст. такого концепту, як «козацький період". 
Джерельна база дослідження включає в себе комплекс праць 3 історії окремих регіонів Наддніпрянської України: Аівобережжя, Півдня та Слобожанщини, а також з історії населених пунктів в цих регіонах.

У сучасній історіографії знайшли відображення окремі аспекти обраної для дослідження теми. Актуальним є використання термінів "козацька" та "післякозацька" доба, що має місце в контексті історії регіональної - Південної України, або у зв'язку 3 історією самого козацтва [2; 3]. Так чи інакше торкаються проблеми ті вчені, які вивчають історіографічну спадщину окремих істориків, присвячену історії козацтва [1. XXXII-XXXVII]. Частково висвітлюється або згадується питання "козацького періоду" та пов'язані з ним к працях, присвячених історії розвитку поглядів на періодизацію історії України [4; 5]. Однак в існуючій історіографії практично відсутня увага до порівняння регіональних особливостей функціонування концепту "козацького періоду", не приділена увага його формуванню в модерній національній та територіальній історіографії.

Звертаючись до вивчення предмету, необхідно відзначити, що "козацький період" як історіографічний концепт-ідея не мав певний час чіткого осмислення в історичних дослідженнях обраного періоду, за певним винятком праць, присвячених історії Південної України. Окремі ознаки концепту з'являлись у працях дослідників переважно відповідно історіографічній традиції, особистим уподобанням авторів, фактичним суб’єктам політичної й народної (суспільної) історії тощо. Однак такий до-теоретичний період функціонування концепту створив необхідні передумови для його теоретичного осмислення, що стало можливим у контексті формування уявлень стосовно загальної історії України. Це осмислення, у свою чергу, відобразилося в окремих працях 3 місцевої історії. У зв’язку з цим, перед безпосереднім аналізом особливостей проявів історіографічного концепту "козацького періоду" в працях з місцевої історії, необхідно звернутися до його відображення в історіографії загальної історії України.

До питання стосовно формування кониепиії "козаиького періоду" $y$ контексті загальної історії Украӥни. Ще у XVIII ст. у працях різних авторів сформувався образ української історії (як історії "Малої Росії») як історії українського народу та козацтва, що іноді розглядалися як синоніми [6]. Поступово відбувалася відмова від ототожнення історії козацтва 3 історією народу, коли козацтво почало розглядатися як феномен в історії українського народу, який його репрезентує. Це простежується в "Истории Русов, или Малой России" [7. 18], "Истории Малороссии" М. А. Маркевича та ін. Останній, зокрема, відзначав, що "початок шістнадцятого століття ознаменовано важливою для малоросіян переміною", коли починається з П. Аянцкоронського "наша Гетманщина" [8, с. 4, 27]. Важливу роль у закріпленні за козацькою тематикою її особливого значення в українській історіографії зіграли також М. О. Максимович, М. І. Костомаров.

У другій половині ХІХ ст. поняття "козацьких часів" популяризував у своїх мекціях у Київському університеті відомий історик, вчитель 
М. С. Грушевського, В. Б. Антонович. Свої «Виклади про козацькі часи на Україні" вчений у академічному 1895-1896 році читав російською мовою в Київському університеті, а українською - приватно. Його мекції були записані студентами та видані (щоправда, за твердженням Д. В. Анто-новича, без редакції автора) в перший раз як "бесіди". У мекціях (викладах) В. Б. Антоновича було відображено спробу осмислити значення в історії України саме козацької доби. У "Передньому слові автора" зазначалося, що для викладів 3 історії України він обрав "період козаччини" з огляду на те, "що в ньому найвиразніше і найяскравіше за все визначилася та провідна ідея, що виявима собою жадання народу". Ця ідея, або "принцип", був "вічевий, принцип широкого демократизму і признання рівного політичного права задля кожної одиниці суспільства ... ця провідна ідея вельми рельєфно визначилася в козаччині, а ще виразніше із погляду запровадження й зреалізування ії у житті - у Запорозькій Січі». Історик також наголошував на тому, що реалізація цієї ідеї ускладнювалася в історії України відсутністю необхідних умов, "доказ на це подає нам найяскравіший момент в історії козаччини - Хмельниччина, коли історичні обставини сприяли найліпше, одначе ж увести в життя провідну ідею українського народу не довелося, бо на те не стало культурного розвитку, переконань та витривалості». Історик простежує історію козацтва в різних формах 3 часів Великого князівства

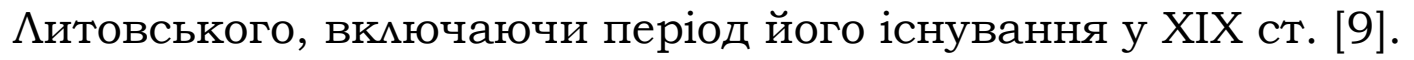

Ідеї періодизації історії України були далі розроблені учнем В. Б. Ан-тоновича М. С. Грушевським. Останній у 1898 р. у передмові до першому тому своєї відомої праці "Історія України-Русі" зазначав, що "досі ми не маємо науково зробленої історії українсько-руського народу, що обіймала б весь час його історичного істновання" [1. [1]].

У “Вступних замітках" до тому М. С. Грушевський виділив найважливіші періоди історії українського народу. Зокрема, він вказав на те, що "...сі дві доби політичного українського життя - стару, княжу і новійшу - народню (козацьку), можна було б назвати тезою й антитезою, що доходять до синтези в столітю українського відродженя" [1, с. 20]. Народну (козацьку) добу, або третій історичний період, коли відбулося "розбудження відпорної енергії національної самоохорони ...", історик розпочинає 3 кінця XVI ст. Це була, за висловом М. С. Грушевського, "недовга, але многоважна доба найбімьшої активності нашого народу як народу». Отже, М. С. Грушевський, подібно В. Б. Антоновичу, використовує поняття "народна (козацька) доба». Тим самим історик сприяв утвердженню не тільки модерної національної концепції історії України, але й формуванню поняття "козацький період" у якості історіографічного концепту в українській національній історіографії.

Кониепиія "козаиького періоду" в контексті місиевої історії: міхк інтегрованими історіографічними підходами та модерною кониепиією національної історії України. Специфіка розвитку історіографії в Наддніпрянської України в обраний період полягала у поєднанні самобутніх, національних рис (коли історія України та історія іiї регіонів 
розглядалася як окрема - народна, державна, або як постдержавна), та інтегрованих характеристик в умовах імперії. Останні включали висвітлення історії Наддніпрянської України як імперського регіону. Те ж стосувалося й менших регіонів, які їі складали: Аівобережної України, Південної України, Правобережної України, Слобідської України, часто з використанням тогочасних термінів в умовах відсутності або початку формування власної відповідної термінології - Новоросійський край, Південно-Західний край. Розмаїття підходів до висвітлення "козацького періоду" в історіографії місцевої історії визначалося й обранням авторами різних предметів дия дослідження, таких, як історія колонізації регіонів, історія політична або соціальна. Це дозволяє виділити три головні типи концепту "козацький період": народницький (демографічний, етнографічний, становий); політич-ний (державнополітичний) (у зв'язку 3 Гетьманщиною чи Запорозькою Січчю); змішаний народницько-політичний концепт (Слобідська Україна).

У контексті вивчення історії Південної Украӥни поняття щодо "козацького періоду" формувалося, на наш погляд, не стільки під впливом власне історіографічних передумов (тобто практики використання поняття у попередній історіографіï), скільки з урахуванням того, що історія козацтва складала й продовжувала у XIX ст. складати важливу частину історії сучасного регіону та суміжних територій (Кубані), куди відбувся відплив козацького населення (Чорноморського козацького війська) наприкінці XVIII ст. Серед українських історіографічних передумов появи цього концепту необхідно згадати погляди козацького мітописця Григорія Грабянки, який на початку XVIII ст. у “Слові до читача заради чого ця історія написана" як передмові до своєї відомої історичної праці "Перебіг презільної і від початку поляків щонайкривавішої небувалої битви Богдана Хмельницького гетьмана запорізького...", або так званого "Аітопису", позначав козацький простір до Чорного моря, маючи на увазі територію, 3 якою пов'язана історія козацтва, яку козаки "розширили" [10]. Не слід виключати й впливу інших праць, вкАючно 3 іноземною історіографією історії України.

Одним 3 перших дослідників, який наповнює зміст одного 3 періодів історії Південної України (переважно) історією козацтва, став ад’ютант герцога А.-Е. де Рішельє Г. де Кастельно. Перше видання його праці під назвою "Нариси давньої та модерної історії Нової Росії" вийшмо у 1820 р., а друге - у 1827 р. у Парижі французькою мовою. В описі матеріалів до другої епохи в історії регіону автор відзначає, що буде вести мову, зокрема, про запорозьких козаків, подвиги яких, за його висловом, "нагадують байки". Відповідно Г. де Кастемьно приділяє багато місця історії козацтва власне під час викладу матеріалів до другої епохи $[11$, с. 3-2,7, 324 та ін.]. Таким чином, Г. де Кастельно використовує до певної міри концепт "козацького періоду" дмя періодизації історії південноукраїнського регіону (пов'язуючи з ним другу епоху в його розвитку), хоча і не обгрунтовує його теоретично, за виключенням наголошення на факті діяльності козацтва. 
Бі^ьш теоретичний характер набувають міркування учасників наукового гуртка в Одесі на початку $1830-\mathrm{x}$ років. Його чмени випускники Московського університету - свідомо обрали періодизацію для визначення стратегії своїх наукових пошуків та студій. Тим самим обрана періодизація більш чітко набула методологічного характеру. Сучасна, або новітня історія півдня України, на думку чценів наукового гуртка, мала розпочинатися "від козацтва" і продовжуватися до 1830-х років. А. О. Скальковський, як чмен цього гуртка, мав займатися новітньою історією [12, с. 54], і саме він від-ділив більш-менш чітко власне самобутню "козацьку добу" (зосереджуючись на історії Нової Січі) в історії регіону від "руського" періоду, хоча іноді його погляди набувають ззовні еклектичного характеру. Це було викликано, зокрема, тим, що він виявляє у окремих своїх працях два підходи до вивчення історії півдня України: державницький та народницький. Тому "руське проникнення у степ" він бачить і як державне, і як народне, за рахунок переселенців, серед яких були і українські козаки (які розглядалися істориком як частина "руського" насемення півдня) [13,с. 7]. С відзначити, що дмя А. О. Скальковського властиво використання двох типів концепту "козацького періоду": народницького та політичного (щодо історії Нової Січі).

Концепт "козацької доби" здебільшого народницького типу простежується й у дослідженнях історії окремих населених пунктів півдня України. Одним з перших, хто звернувся до теми історії населених пунктів на території півдня (а саме Нової Січі), був колишній запорожець М. $\Lambda$. Корж, який залишив свої "оповіді", упорядковані архієпископом Гавриїном (В. Ф. Розановим) [14]. Звертаючись до історії міста Катеринослава у розвідці "Про початок міста Катеринослава" [14, c. 55-61], М. $\Lambda$. Корж простежує зміни назв міста, за його характерними виразами, "починаючи від давніх часів запорозьких", або "після Запорожжя" [14, с. 57,60$]$. Крім того, він подає певну інформацію щодо історії населених пунктів на території Січі, розвитку окремих козацьких зимівників, походження назв, які існували ще до 1775 р. Один 3 розділів його записок так i названий: "Про стародавні запорозькі селища, що були ще до атакування Січі" [14, с. 84-94]. Всього селищ М. $\Lambda$. Корж нараховує 17 , тоді як, на його думку, "...на інших місцях, по всіх Запорозьких володіннях, були одні тільки зимівники, хутори i курені (шалаши) козацькі, як у кочуючих Ногайців..." [14, с. 93].

Інший автор, відомий українофіл Я. П. Новицький, присвятивши свою працю історії міста Олександрівська Катеринославської губернії (перше видання здійснено місцевим земством у 1905 р.), використав свідчення старожилів, матеріали запорозького архіву та інші джерела. Його усвідомлення припинення "козацького періоду" в історії місцевості, на якій розташований Олександрівськ, відображено у наступних міркуваннях: "...Олександрівськ заснований на попелищі козачих зимівників, ... за корінним складом населення тут багато малоросів, нащадків "слобожан" і "гетьманців", багато нащадків "Війська славного Запорозького, Низового»...". Їм автор і присвятив 
свою працю. Слід відзначити, що Я. П. Новицький не тільки згадує про попередній козацький період в історії міста, негативну реакцію запорожців на заснування фортеці (що, на думку автора, означамо заснування міста), але, звертаючись до історії власне Олександрівська, простежує наявність колишніх запорожців та іншого козацтва у його населенні після заснування [15, с. 185-186, 198, 217].

Ще один відомий дослідник історії півдня України, архієпископ Гавриї^ (В. Ф. Розанов), звертаючись до історії Херсонської та Таврійської єпархії на півдні України, мав на меті визначити особливості заснування окремих населених пунктів, переважно сіл, іноді зупиняючись більш докладно на дальшому розвитку. У зв'язку 3 цим його внесок у використання концепту "козацького періоду" обмежувався практично фактами про козацьке заснування населеного пункту. Зокрема, звертаючись під 1766 р. до історії с. Мелеківки Бобринецького повіту, автор використовував місцевий переказ про те, що назва села походить від першого жителя-запорожця, що мав прізвисько Аелека [16, с. 10].

Прикладом висвітлення історії міст на півдні України є праця 3 історії Катеринослава, що була підготовцена М. М. Вцадимировим та видана у 1887 р. як ювілейна [17]. Серед іншого автор, наводячи відомості щодо заснування 2-го Катеринослава, відзначає, що для цього був обраний правий берег Дніпра між Новим та Старим Кайдаками, "саме те місце, на якому знаходимась старожитня козацька слобода Половиця", час заселення якої невідомий (вона згадується в одному з ордерів у 1764 р.). Крім того, автор посилається на спогади М. . Коржа, що заселення слободи почалося тоді, коли його предки зайшми "в цю украйну". М. М. ВАадимиров вказує на значення Половиці для козаків, яке, на його думку, дорівнювало Києву (тут були монастирські володіння), подає історичний нарис 3 XIII ст., вказує на заснування тут зимівників та хуторів козаками близько 1750 р. [17, с. 30-35].

Особливе місце концепт "козацького періоду" займає в історіографії місцевої історії Аівобережної України, що раніше входила до складу Аівобережної Гетьманщини. Необхідно відзначити, що, відповідно історичним умовам вцастивими $\epsilon$ також два типи концепту "козацького періоду" народницький та державно-помітичний.

Використання першого типу простежується у працях О. М. Аазаревського, присвячених історії сіл регіону. Головний мейтмотив історії сіл колишньої Гетьманщини у зображенні дослідника - це історія втрати їх козацьким (за станом) населенням свого статусу та перетворення його на "підданих", що, у свою чергу, виступало стимулом дмя початку боротьби колишніх козаків за відновцення своїх прав. Представляє інтерес те, що історія сіл дозволила історику практично в середині "козацького періоду" (в сенсі державно-політичному) виділити

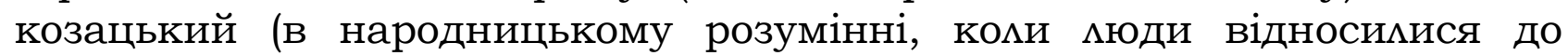
козацького стану) та некозацький період, як період втрати козацького 
стану ї мешканцями (або частиною мешканців), тобто переходу до "підданства". Прикладом є розвідки історика, зібрані у праці "Исторические очерки сел Конотопского уезда", зокрема, стосовно сіл Великий та Малий Самбір, Дентівка [18, с. 12-16]. Заснування Дентівки історик відносить до середини XVII ст., робить припущення, що вона було засноване, "можливо, під час війн Хмельницького "нахожими" 3

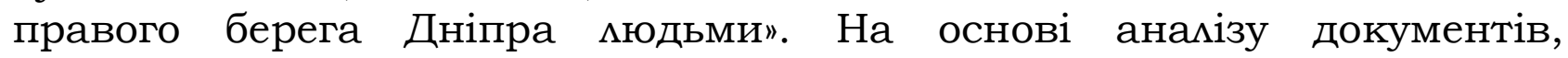
фрагменти яких наводяться в тексті, автор робить висновок про те, що поселення наприкінці XVII ст. було селом з усіма ознаками: "у 1699 р. у Дентовці був вже ктитор, отаман і війт, тобто була вже церква та значне населення: у козаків - отаман, у посполитих селян - свій війт». Далі автор простежує, як село то потрапляло у приватну вцасність, то знову перетворювалося у "вільне військове село", а з часом - знову у приватне володіння. Далі історія села була відзначена тільки зміною приватних вмасників.

Державно-політичний концепт "козацького періоду" (з включенням елементів народницького) відображений в історії м. Чернігова, що з'явилася в контексті святкування ювілеїв міст, початок яких пов'язаний з історією Київської Русі. Ювілейне видання "Очерк истории города Чернигова, 907-1907" побачимо світ у 1908 році [19]. Автор запропонував періодизацію історії міста, засновану на державницькополітичному підході: Чернігів князівсько-вічового періоду (907-1356); Аитовський період (1356-1503); Московський період (1503-1618); Польський період (1618-1654); Період Гетьманський (1654-1722); Перехід до загальноімперського управління (1722-1782); Чернігів та його громада до реформ Катерини II; Введення у дію Катерининських установ (1782-1870); Період пореформений.

Слід відзначити, що у цій схемі період Гетьманщини визначений як рівноправний іншим періодам державно-політичного підпорядкування Чернігова. Звертає на себе увагу те, що автор виключає 3 "періоду Гетьманського" добу обмеження прав Гетьманщини, з 1722 р., тобто цей період практично розглядається як перехідний, а не самобутній. Водночас і під час характеристики інших періодів в історії міста автор включає відомості стосовно появи та ролі козацтва в історії Чернігівщини, що дозволяє віднести їх до концепції "козацького періоду" народницького характеру. Зупиняючись безпосередньо на питанні формування козацтва в регіоні, автор відзначає, що причинами появи козаків як "класу напіввійськових степових промисловиків (здобичників)" було розташування Чернігова на кордоні

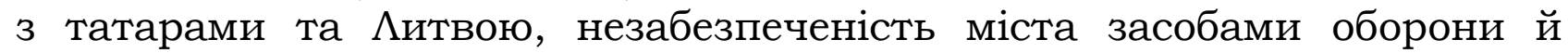
ініціатива місцевого населення, яке 3 свого середовища створило цей "клас". Серед іншого, вказується на те, що "козаки для нижчого класу стали ідеалом рицаря та громадянина", створюючи на Чернігівщині особливу систему цінностей $[19$, с. 15-16].

Особливий інтерес представляє концепт "козацького періоду", відображений в окремих працях з історії населених пунктів Слобідсъкої України, що з'явилися на початку XX ст. В них зустрічається змішаний 
народницько-помітичний тип концепту "козацького періоду", який, на наш погляд, демонструє вплив теоретичної модемі періодизації історії України в національній історіографічній парадигмі В. Б. Антоновича та М. С. Гру-шевського. Прикладом цього є дослідження Д. І. Багалія та Д. І. Мілмера "История города Харькова" (т. 1, 1905) [20]. Необхідно відзначити, що Д. І. Багалій, як і М.С. Грушевський, був учнем В. Б. Антоновича. Тому ми можемо припустити існування прямого впливу концепції періодизації загальної історії України модерного типу на історичне дослідження авторів історії Харкова. Як теоретичне підгрунтя дия свого дослідження, Д. І. Багалій розглядав питання періодизації. У передмові до книги він, зокрема, відзначав, що історія Харкова, включаючи XVII, XVIII та XIX ст., "..охоплює всі сторони міського життя у давній козацький період, епоху реформи, що наслідувала йому, коли відбувалася міквідація колишнього своєрідного устрою та побуту, і у XIX столітті..." [20, с. 3]. Перший том досиідження історії м. Харкова і був присвячений "козацькому періоду" та періоду реформ, нагадуючи згаданий вище підхід, використаний при написанні історії м. Чернігова. Ми віднесли використаний Д. І. Багалієм та Д. І. Мілцером концепт "козацького періоду" до змішаного типу народницько-політичного, 3 огляду на особливості козацького самоврядування в Слобідській Україні та увагу авторів до характеристики різних аспектів життя місцевого населення, від питань колонізації і адміністрації до освіти.

Таким чином, в умовах формування модерної української нації відбуваються зміни у підходах до висвітлення української історії, формується самобутня національна парадигма цієї історії. У зв'язку 3 цим відбувається зміна ставлення до історії козацтва. Якщо спершу вона розглядалося як синонім до українського народу, або як така, що репрезентує вцасне українську історію, то згодом, 3 розширенням в історіографії хронології історії України, час існування козацтва перетворюється на іï важливий черговий етап, який зберігає виняткове значення й для наступного історичного розвитку. Водночас історичні дослідження в Наддніпрянській Україні територіального, місцевого характеру теж містили в собі відображення спроб виділити концепт "козацького періоду". Внаслідок проведеного дослідження було з'ясовано, що в різних регіонах Наддніпрянської України в історіографії місцевої історії (регіонів та населених пунктів) існували особливі типи концепту "козацького періоду", в залежності від історичного досвіду, підходів окремих авторів та ін. Їх можна поділити на три типи: народницький (демографічний, етнографічний, становий); політичний (державно-політичний) та змішаний народницько-політичний. Вплив концепту "козацького періоду", вмастивого національній парадигмі історії України В. Б. Антоновича - М. С. Грушевського, згідно використаним джерелам, найбільше відображений у праці 3 історії міста Харкова (1905), за авторством Д. П. Мілмера та Д. І. Багалія, що був учнем В. Б. Антоновича, хоча не можна виключати його вплив і на авторів дослідження з історії м. Чернігова (1908). 


\section{Джерема та мітература:}

1. Грушевський М. С. Історія України-Руси : в 11 т., 12 кн. / Редкол. : П. С. Сохань (голова) та ін. - К. : Наук. думка, 1991. - Т. 1. - 1994. - 736 с. - (Пам'ятки іст. думки України).

2. Бачинська О. А. Козацтво в "післякозацьку" добу української історії (кінець XVIII - XIX ст.) / О. А. Бачинська. - К. : Вища шк., 2011. - 287 с.

3. Південна Україна : козацька та після козацька доба (XVI-XX ст.) : матеріали Міжнародних наукових читань, Одеса, 26-27 травня 2012 р. - Одеса : СПД Бровкін, 2012. - 112 с.

4. Кумьчицький С. Періодизація вітчизняної історії у працях Інституту історії НАНУ / С. Кумьчицький // Український історичний журнал. - 2011. - № 3. C. 161-173.

5. Потульнииький $B$. Схеми періодизації історії України в українській історіографіiі 19 - 20 ст. : проблеми теорії та методології / В. Потульницький // Спеціальні історичні дисципліни : питання теорії та методики. - К., 2000. - Т. 5. Ч. 2. - С. 434-461.

6. Симоновский П. И. Краткое описание о козацком малороссийском народе и о военных его делах, собранное из разных историй иностранных, немецкой Бишенга, матинской - Безольди, фрранцузской - Шевалье и рукописей русских, через Бунчукового товарища Петра Симоновского 1765 года / П. И. Симоновский. - Москва : б. и., 1847. - [8], 159, 17, [1] с.

7. Кониский Г. История Русов или Малой России, сочинение Георгия Конискаго, Архиепископа Беморусского. - Москва : В университетской тип., 1846. - IV, [2], 257, [5], 45 c.

8. Маркевич Н. История Малороссии : [в 5 т.] / Никомай Маркевич. - Москва : Тип. Августа Семена, 1842. - Т. 1. - 387, Х с.

9. Антонович В. Про часи козацькі на Україні / Володимир Антонович. - К. : Вид-во худ. міт-ри "Дніпро", 1991. - Режим доступу : http:/ / exlibris.org.ua/kz/index.html (останній перегляд - 15.09.2018).

10. Грабянка Г. Мітопис гадяцыкого полковника Григорія Грабянки / Г. Грабянка ; пер. із староукр. - К. : Т-во "Знання" України, 1992. - 192 с.

11. Castelnau, Gabriel de. Essai sur l'Histoire ancienne et modern de la Nouvelle Russie / G. de Castelnau. - 2 edition. - A Paris, 1827. - T. 1. - 355 p.

12. Хмарський В. М. 3 історії розвитку археографії на Півдні України : Апомлон

Скальковський / В. М. Хмарський / / Записки історичного факультету. - Одеса, 1998. - Вип. 6. - 318 с.

13. Скальковский А. Хронологическое обозрение истории Новороссийского края, составленное Апомлоном Скальковским, комлежским ассесором, кандидатом прав, членом общества сельского хозяйства Южной России / Апомлон Скальковский. - Одесса : В Гор. тип., 1836. - Ч. 1 : с 1731 по 1796 год. - [4], XI, [3], 289 c.

14. Корж Н. $\Lambda$. Устное повествование бывшего запорожца, жителя Екатеринославской губернии и уезда, селения Михайловки, Никиты Аеонтьевича Коржа / Н. А. Корж. - Одесса : В Гор. тип., 1842. - 95 с.

15. Новицкий Я. П. История города Александровска в связи с историей возникновения крепостей Днепровской минии, 1770-1806 / Я. П. Новицкий // Новицький Я. Твори : у 5 т. - Запоріжжя, 2007. - Т. 1. - С. 184-303.

16. Гавриил [В. Ф. Розанов], архиепископ Херсонский. Историкохронологическое описание церквей епархии Херсонской и Таврической / Гавриил, Архиепископ Херсонский и Таврический, ныне Тверской и Кашинский. - Одесса, 1848. - 71 с. 
17. Владимиров М. М. Первое столетие г. Екатеринослава, 1787 - 9 мая 1887. Доклад Екатеринославской Городской Управы к торжественному заседанию Думы 9 мая 1887 г. : материалы дия исторического очерка / Сост. М. М. Владимиров, гор. секретарь. - Екатеринослав : Тип. Я. М. Чаусскаго, 1887. - 4, II, III, $275 \mathrm{c}$.

18. Мазаревский А. М. Исторические очерки сел Конотопского уезда : Юговосточная часть уезда / А. М. Аазаревский. - Чернигов: Тип. Губ. Правления, 1886. - 33 c.

19. Очерк истории города Чернигова, 907-1907 : юбил. изд. Чернигов. Гор. Управы. - Чернигов : Тип. Губ. Земства, 1908. - 71 с.

20. Багалей Д. И., Мимлер Д. П. История города Харькова за 250 мет его существования ( с 1655-го по 1905-й год) : историческая монографрия / Д. И. Багалей, Д. П. Мимлер. - Т. 1 : XVII-XVIII века. - Харьков, 1905. - 569 с.

\section{References:}

1. Hrushevsky M. S. Istoriia Ukrainy-Rusi [The History of Ukraine-Rus']. K. : Nauk. Dumka, 1991. T. 1. 736 s. [in Ukrainian].

2. Bachyns'ka O. A. Cozatsvo v "pisliacozats'ku" dobu ukrains'koi istorii (kinets' XVIII - XIX st.) [The Cossacks in "Post-Cossack" Period of Ukrainian History (the end of XVIII - XIX c.]. K. : Vyscha shkola, 2011. 287 s. [in Ukrainian].

3. Pivdenna Ukraina : cozats'ka ta pisliacozats'ka doba (XVI-XX c.) : materialy Mizhnarodnykh naukovykh chytan', Odesa, 26-27 travnia 2012 r. [The Southern Ukraine: The Cossack and Post-Cossack epochs (XVI-XX c.)]. Odesa : SPD Brovkin, 2012. 112 c. [in Ukrainian].

4. Kul'chyts'kyi S. Periodyzatsiia vitchyznianoii istorii u pratsiakh Instytutu istorii NANU [The Periodization of Native History in the works of Institute of History NANU] // Ukraiins'kyi istorychnyi zhurnal. 2011. № 3. C. 161-173. [in Ukrainian].

5. Potul'nytskyi V. Skhemy periodyzatsii istorii Ukrainy v ukrains'kii istoriographii 19 - 20 st. : problemy teorii ta metodologii [The Schemes of Periodization of History of Ukraine 19 - 20 c. : the problems of theory and methodology] // Spetsial'ni istorychni dystsypliny : pytannia teorii ta metodyky. K., 2000. T. 5. Ch. 2. C. 434461. [in Ukrainian].

6. Symonovskij P. I. Kratkoie opisaniie o cozatskom malorossiiskom narodie i o voennykh iego dielakh, sobrannoie iz raznykh istorij inostrannykh, niemietskoj Bishenga, latinskoj - Bezol'di, frantsuzskoj - Shevaljie i rukopisiej russkikh, cherez Bunchukovogo tovarischa Petra Simonovskogo, 1765 goda [The Brief Description of Cossack Little Russia People and Its Military affairs]. Moskva, 1847. [8], 159, 17, [1] s. [in Russian].

7. Koniskij G. Istoriia Rusov ili Maloj Rossii, sochinieniie Georgiia Koniskogo, Arkhiiepiskopa Belorusskogo [The History of Rusy or Little Russia]. Moskva : V universitetskoj tip., 1846. IV, [2], 257, [5], 45 s. [in Russian].

8. Markewvich N. Istoriia Malorossii [History of Malorossia (Little Russia)]: [v 5 T.]. Moskva : Tip. Avgusta Siemiona, 1842. T. 1. 387, X s. [in Russian].

9. Antonovych V. Pro chasy cozats'ki na Ukraini [On the Cossacks Times in Ukraine].

K. : Vyd-vo khud. lit-ry "Dnipro». 1991. [in Ukrainian].

10. Grabianka G. Litopys gadiats'kogo polkovnyka Grygoriia Grabianky [The Colonel of Gadiach Grygorij Grabianka's Chronicle]. K. : T-vo "Znannia», 1992. 192 c.

11. Castelnau, Gabriel de. Essai sur 1'Histoire ancienne et modern de la Nouvelle Russie / G. de Castelnau. - 2 edition. - A Paris, 1827. - T. 1. - 355 p. [in French].

12. Khmars'kyi V. M. $Z$ istorii rozvytku arkheographii na Pivdni Ukrainy : Apollon Skal'kovs'kyi [From the History of Archeography in South of Ukraine : Apollon 
Skal'kovs'kyi] // Zapysky istorychnogo facul'tetu. Odesa, 1998. Vyp. 6. 318 s. [in Ukrainian].

13. Skal'kovs'kij A. Khronologicheskoie obozrieniie istorii Novorossijskogo kraia [The Chronological Review of the History of New Russia Region]. Odessa : V Gor. tip., 1836. Ch. 1 : s 1731 po 1796 god. [4], XI, [3], 289 s. [in Russian].

14. Korzh N. L. Ustnoie povestvovaniie byvshego zaporozhtsa, zhytielia Ekaterinoslavskoj gubernii i uiezda, seleniia Mikhajlovki, Nikity Lieontiievicha Korzha [The former Zaporozhian Cossack's Oral Narration ]. Odessa : V. Gor. tip., 1842. 95 s. [in Russian].

15. Novitskij Ia. P. Istoriia goroda Aleksadrovska v sviazi s istoriiej vozniknovieniia krepostiej Dnieprovskoj linii, 1770-1896 [The History of the Town Alexandrovsk in Connection With the History of Emerging of Fortresses of Dnieper Line, 1770-1896] // Novyts'kyi Ia. Tvory. Zaporizhzhia, 2007. T. 1. C. 184-303. [in Russian].

16. Gavriil [V. F. Rozanov], arkhiiepiskop Khersonskij. Istoriko-khronologicheskoie opisaniie tserkviej eparkhii Khersonskoj i Tavricheskoj [The Historical and Chronological Description of the Churches of Kherson and Tavriia Diocese]. Odessa, 1848. 71 c. [in Russian].

17. Vladimirov M. M. Piervoie stolietiie g. Ekatierinoslava, 1787 - 9 maia 1887. Doklad Ekaterinoslavskoj Gorodskoj Upravy k torzhestvennomu zasiedaniiu Dumy 9 maia 1887 g. : materialy dlia istoricheskogo ocherka [The First Centenary of c. Ekaterinoslav, 1787 - 9 of May 1887]. Ekatierinoslav : Tip. Ia. M. Chausskogo, 1887. 4, II, III, 275 s. [in Russian].

18. Lazarevskij A. M. Istoricheskiie ocherki siol Konotopskogo uiezda : IugoVostochnaia chast' uiezda [The Historical Essays for Villages of Konotop County : South-East Part of the County]. Chernigov : Tip. Gub. Pravlieniia, 1886. 33 c. [in Russian].

19. Ocherk istorii goroda Chernigova, 907-1907 [The Essay of History of the City of Chernigov, 907-1907]: iubil. izd. Chernigov. Gor. Upravy. Chernigov : Tip. Gub. Zemstva, 1908. 71 s. [in Russian].

20. Bagaliej D. I., Miller D. P. Istoriia goroda Khar'kova za 250 liet iego suschestvovfniia (s 1655-go po 1905-j god) : istoricheskaia monografiia [The History of City of Kharkov During 250 Years of Its Existence (from 1655 up to 1905)] T. 1 : XVII-XVIII veka. Khar'kov, 1905. 569 s. [in Russian].

\section{"Период казачества" как историографический кониепт в трудах по местной истории Надднепрянской Украины, XIX - начало XX 6.}

В статье поставлена проблема существования историографического кониепта "период казачества" в историографии местной истории Надднепрянской Украины эпохи формирования модерной украинской наиии. В это время историография истории Украины постепенно преврашается в самостоятельное направление исследований, что осуијествлялось, $в$ частности, с помощью формирования собственной периодизаиии наииональной истории. В связи с этим, традииионная казачья тематика, которая признавалась украинской в условиях Российской империи, в определенной степени утрачивала роль единственного репрезентанта истории Украины.

Украинская историография расширяла образ истории Украины в более древние времена, например, за счет Руси (в контексте кониепиии Руси-Украины В. Б. Антоновича и М. С. Грушевского) и далее, а также осмьсливала самобьтное современное развитие украинского обиества как период национального возрождения. Соответственно эпоха появления и развития 
казачества как отдельного украинского исторического феномена преврачалась в очередной этап в истории Украины в модерной модели (парадигме) ее исторического развития. Поэтому в статье уделяется внимание становлению кониепта "периода казачества" в контексте обией истории Украины. В то же время исторические исследования в Надднепрянской Украине - не обиенаиионального украинского, а территориального, местного характера также отображали попытки выделить кониепт "периода казачества", потому что они рассматривали все доступные по источникам периоды в истории регионов (от античности (в условиях юга) до современности или, в истории отдельных населенных пунктов - последовательную смену периодов, начиная от их основания.

B cтатье также уделено внимание разньим подходам авторов $\kappa$ использованию кониепта "периода казачества" в историографии местной истории, предложено выделить три типа кониепта: народнический (демографический, этнографический, сословный); политический (государственнополитический) (в связи с Гетманшиной или Запорожской Сечью); смешанный народническо-политический (Слободская Украина).

В результате проведеного исследования было выяснено, ито в историографии истории разных регионов Надднепрянской Украины сушествовали особые типы кониепта "периода казачества", в зависимости от местного исторического опьта, подходов отдельных авторов и $\mathrm{m}$. д. Влияние кониепта "периода казачества", присущего наииональной парадигме истории Украины В. Б. Антоновича - М. С. Грушевского, согласно использованнъм источникам, наиболее заметно в истории города Харькова, за авторством Д. И. Багалея, который был учеником В. Б. Антоновича, хотя нельзя исключать ее влияние и на авторов истории г. Чернигова.

ключевые слова: кониепт "периода казачества", модерная историография Украины, историография истории отдельных регионов Украины, историография истории населенных пунктов Надднепрянской Украины.

Отримано 01.12.2018р. 